\title{
New fossils from the Paleogene of central Libya illuminate the evolutionary history of endemic African anomaluroid rodents
}

\section{OPEN ACCESS}

Edited by:

Zerina Johanson,

Natural History Museum, UK

Reviewed by:

Ross MacPhee,

American Museum of Natural History and Gilder Graduate School, USA

Jürgen Kriwet,

University of Vienna, Austria

Graciela Helena Piñeiro,

Universidad de la República, Uruguay

*Correspondence:

K. Christopher Beard, Biodiversity Institute, University of Kansas, 1345 Jayhawk Boulevard,

Lawrence, KS 66045, USA chris.beard@ku.edu

Specialty section:

This article was submitted to Paleontology,

a section of the journal Frontiers in Earth Science

Received: 06 August 2015 Accepted: 08 September 2015 Published: 06 October 2015

Citation:

Coster PMC, Beard KC, Salem MJ, Chaimanee $Y$ and Jaeger J-J (2015) New fossils from the Paleogene of central Libya illuminate the evolutionary history of endemic African anomaluroid rodents. Front. Earth Sci. 3:56.

doi: 10.3389/feart.2015.00056

\section{Pauline M. C. Coster ${ }^{1,2}$, K. Christopher Beard ${ }^{1,2 *}$, Mustafa J. Salem ${ }^{3}$, Yaowalak Chaimanee ${ }^{4}$ and Jean-Jacques Jaeger ${ }^{4}$}

${ }^{1}$ Biodiversity Institute, University of Kansas, Lawrence, KS, USA, ${ }^{2}$ Department of Ecology and Evolutionary Biology, University of Kansas, Lawrence, KS, USA, ${ }^{3}$ Geology Department, Tripoli University, Tripoli, Libya, ${ }^{4}$ Institut de

Paléoprimatologie et Paléontologie Humaine: Évolution et Paléoenvironnements, Université de Poitiers, Poitiers, France

Anomaluroid rodents show interesting biogeographic and macroevolutionary patterns, although their fossil record is meager and knowledge of the natural history of extant members of the clade remains inadequate. Living anomaluroids (Anomaluridae) are confined to equatorial parts of western and central Africa, but the oldest known fossil anomaluroid (Pondaungimys) comes from the late middle Eocene of Myanmar. The first appearance of anomaluroids in the African fossil record coincides with the first appearances of hystricognathous rodents and anthropoid primates there. Both of the latter taxa are widely acknowledged to have originated in Asia, suggesting that anomaluroids may show a concordant biogeographic pattern. Here we describe two new taxa of African Paleogene anomaluroids from sites in the Sirt Basin of central Libya. These include a new Eocene species of the nementchamyid genus Kabirmys, which ranks among the oldest African anomaluroids recovered to date, and a new genus and species of Anomaluridae from the early Oligocene, which appears to be closely related to extant Zenkerella, the only living non-volant anomalurid. Phylogenetic analyses incorporating the new Libyan fossils suggest that anomaluroids are not specially related to Zegdoumyidae, which are the only African rodents known to antedate the first appearance of anomaluroids there. The evolution of gliding locomotion in Anomaluridae appears to conflict with traditional assessments of relationships among living anomalurid taxa. If the historically accepted division of Anomaluridae into Anomalurinae (extant and Miocene Anomalurus and Miocene Paranomalurus) and Zenkerellinae (extant and Miocene Zenkerella and extant /diurus) is correct, then either gliding locomotion evolved independently in Anomalurinae and Idiurus or non-volant Zenkerella evolved from a gliding ancestor. Anatomical data related to gliding in Anomaluridae are more consistent with a non-traditional systematic arrangement, whereby non-volant Zenkerella is the sister group of a clade including both Anomalurus and Idiurus.

Kabirmys prius: urn:Isid:zoobank.org:act:C4FC0114-DAA6-4D12-BD3C-F5900BE1AD1E Prozenkerella: urn:Isid:zoobank.org:act:144DC508-333F-4746-A313-A0556804D7F1 Prozenkerella saharaensis: urn:Isid:zoobank.org:act:76992C9D-D754-40E9-B8E2-E786A5BC7E8C urn:Isid:zoobank.org:pub:866B8A65-BCB2-4E8F-B6FA-24637606528C

Keywords: Eocene, Oligocene, Nementchamyidae, Anomaluridae, gliding, phylogeny, biogeography 


\section{Introduction}

Living Anomaluridae, also known as African scaly-tailed flying squirrels, are an endemic rodent clade found only in the forests of western and central Africa (Happold, 2013). This distinctive family of rodents was first described in the nineteenth century as European naturalists began to explore the rainforests of equatorial Africa (e.g., Waterhouse, 1842; Gervais, 1849, 1853; Fraser, 1852; Thomas, 1887; Matschie, 1894, 1898). Little is known about the general biology of Anomaluridae, including basic aspects of their ecology, behavior and evolutionary history. Anomaluridae includes seven extant species and three living genera that are typically segregated into two subfamilies based on morphological similarities: the Anomalurinae (Anomalurus) and the Zenkerellinae (Idiurus and Zenkerella) (Wilson and Reeder, 2005). This traditional systematic arrangement of living anomalurids has yet to be tested by modern molecular phylogenetic approaches, primarily because of the absence of genomic data for extant Zenkerella.

Anomaluridae are highly modified for arboreal life, and all anomalurids aside from Zenkerella insignis are capable of gliding locomotion (e.g., Happold, 2013). Zenkerella, also known as the flightless scaly-tailed squirrel or Cameroon scaly-tail, is poorly documented, even for an anomalurid. Only a few specimens of Zenkerella are represented in museum collections worldwide, although it was first discovered more than a century ago (Matschie, 1898). Virtually nothing is known about its natural history, and its phylogenetic relationships with respect to other members of the family remain enigmatic. The fact that Zenkerella is the only living anomalurid that lacks a patagium and is thus incapable of gliding suggests that this genus could be phylogenetically basal with respect to the gliding taxa Idiurus and Anomalurus. However, certain craniodental characters have been cited as support for a Zenkerella + Idiurus clade (Zenkerellinae) (e.g., Matschie, 1898; Ellerman, 1940). If Zenkerella is the sister group of Idiurus or if it is otherwise phylogenetically nested among other living anomalurids, then either Zenkerella has secondarily lost the ancestral anomalurid patagium or gliding has evolved independently in Idiurus and Anomalurus (Figure 1).

The fossil record of anomalurids and their close relatives is meager. The Neogene record of anomalurids includes Zenkerella wintoni and two species of the extinct genus Paranomalurus, all of which are documented from the early Miocene of Kenya and Uganda (Lavocat, 1973; Pickford et al., 2013). Otherwise, a fossil species of Anomalurus has been reported from the middle Miocene Muruyur Beds of western Kenya (Winkler, 1992). More recently, Shazurus minutus has been described from the earliest late Eocene BQ-2 locality in Egypt as the oldest known occurrence of Anomaluridae (Sallam et al., 2010a).

In addition to the living and fossil members of Anomaluridae, two extinct anomaluroid families, the Nonanomaluridae and the Nementchamyidae, have been described. The only known



D

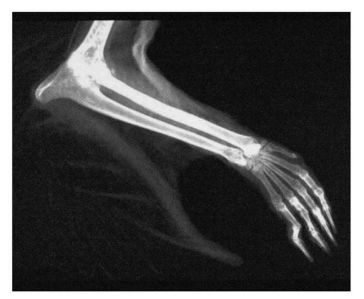

B

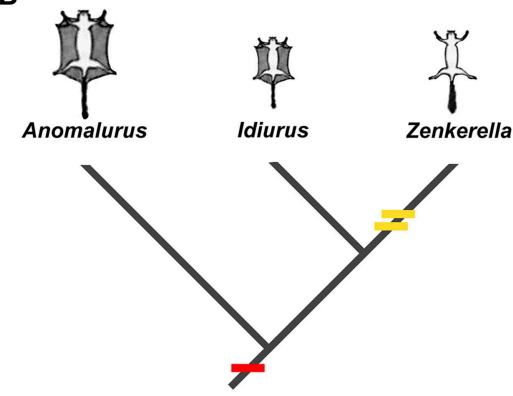

C



E

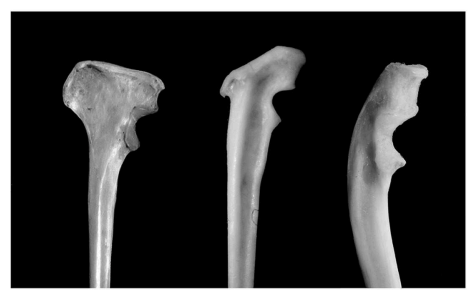

$\mathbf{F}$

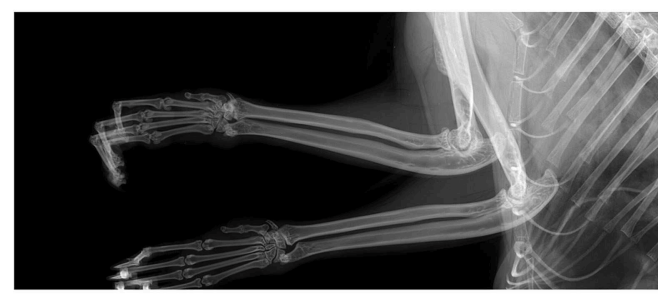

FIGURE 1 | Osteological markers and alternative interpretations of the evolution of gliding in living Anomaluridae (red bars indicate acquisition of gliding, yellow bar signifies loss of gliding). (A) cladogram depicting conventional relationships among crown anomalurids with convergent acquisition of gliding in extant Anomalurus and Idiurus; (B) cladogram depicting conventional relationships among crown anomalurids showing early acquisition of gliding in crown anomalurids and secondary loss of gliding by Zenkerella; (C) cladogram depicting unconventional relationships among crown anomalurids showing retention of non-volant locomotion in Zenkerella and homologous acquisition of gliding by the Anomalurus + Idiurus clade; (D) x-ray of the bones of the forearm and styliform cartilage of Anomalurus derbianus (from Jackson, 2012: 5); (E) from left to right (not to scale): Anomalurus derbianus proximal ulna from the Museum für Naturkunde (ZMB 25307), Idiurus macrotis proximal ulna from the Museum für Naturkunde (ZMB 22754), Zenkerella insignis proximal ulna from the Museum für Naturkunde (ZMB 10085); (F) x-ray of the bones of the forearm of Zenkerella insignis from the Royal Museum of Central Africa (RMCA 28806) showing the absence of styliform cartilage. 
representative of the Nonanomaluridae is Nonanomalurus soniae from the early Miocene of East Africa (Pickford et al., 2013). Members of the Nementchamyidae have been described from the early late Eocene BQ-2 locality in Egypt (Kabirmys qarunensis; Sallam et al., 2010b) and from the roughly contemporaneous Bir el-Ater site in Algeria (Nementchamys lavocati; Jaeger et al., 1985). Currently, the nementchamyid Pondaungimys anomaluropsis from the late middle Eocene Pondaung Formation in central Myanmar is the oldest known occurrence of an anomaluroid worldwide, as well as one of the few occurrences of anomaluroids outside of Africa (Dawson et al., 2003; Marivaux et al., 2005). The only other Asian anomaluroid currently known is Downsimys margolisi from the Oligocene of the Bugti Hills in central Pakistan (Flynn et al., 1986; Marivaux and Welcomme, 2003). Afro-Arabian anomaluroids have also been reported from the early Oligocene of Oman (Thomas et al., 1999), but these fossils have not yet been published.

The broader phylogenetic relationships of anomaluroid rodents remain problematic. Molecular phylogenetic results suggest that extant Pedetidae (spring hares) are the nearest living relatives of Anomaluridae, and the putative clade including Pedetidae and Anomaluridae has been called Anomaluromorpha (Montgelard et al., 2002, 2008). However, a wide anatomical and ecological gap separates living pedetids (which are terrestrial, saltatory bipeds adapted to relatively open terrain) and anomalurids (which are arboreal gliding and non-gliding forms adapted to forested conditions). If these living African rodent clades are closely related, it stands to reason that early Cenozoic African rodents might be specially related to them. One group of African fossil rodents that has been cited as potentially being related to anomaluroids is the Zegdoumyidae, which are known from the late early Eocene and/or early middle Eocene of Algeria and Tunisia (Vianey-Liaud et al., 1994; Marivaux et al., 2011 2015) and younger Eocene sites in Namibia (Pickford et al., 2008). Zegdoumyids are the oldest known African rodents and have been mentioned as a possible stem group for the crown clade Anomaluridae (Vianey-Liaud et al., 1994; Marivaux et al., 2005, 2011; Sallam et al., 2010a,b).

Here we augment the African fossil record of anomaluroid rodents by describing two new taxa from the Eocene and Oligocene of the Sirt Basin in central Libya. These are the first members of this clade to be described from Libya. These new anomaluroid taxa provide the basis for a reassessment of the phylogenetic and biogeographic history of this distinctive group of rodents.

\section{Materials and Methods}

\section{Geological Context and Specimens}

Over the past decade, our team has conducted paleontological and geological research along the Dur At-Talah escarpment and in the vicinity of Zallah Oasis, both of which are in the Sirt Basin, central Libya (Figure 2).

The Dur At-Talah escarpment, located in the southern part of the Sirt Basin, consists of $150 \mathrm{~m}$ of mainly clastic rocks divided into two stratigraphic units: the New Idam Unit at the base composed of fine sand/claystone alternations and the Sarir Unit at the top dominated by sandstones. Abouessa et al. (2012) provided a recent synthesis of the stratigraphy, sedimentology, and depositional environments of Eocene rocks comprising the Dur At-Talah escarpment. The New Idam Unit has yielded one of the richest Paleogene faunas known from North Africa including both lower vertebrates and placental mammals (Savage

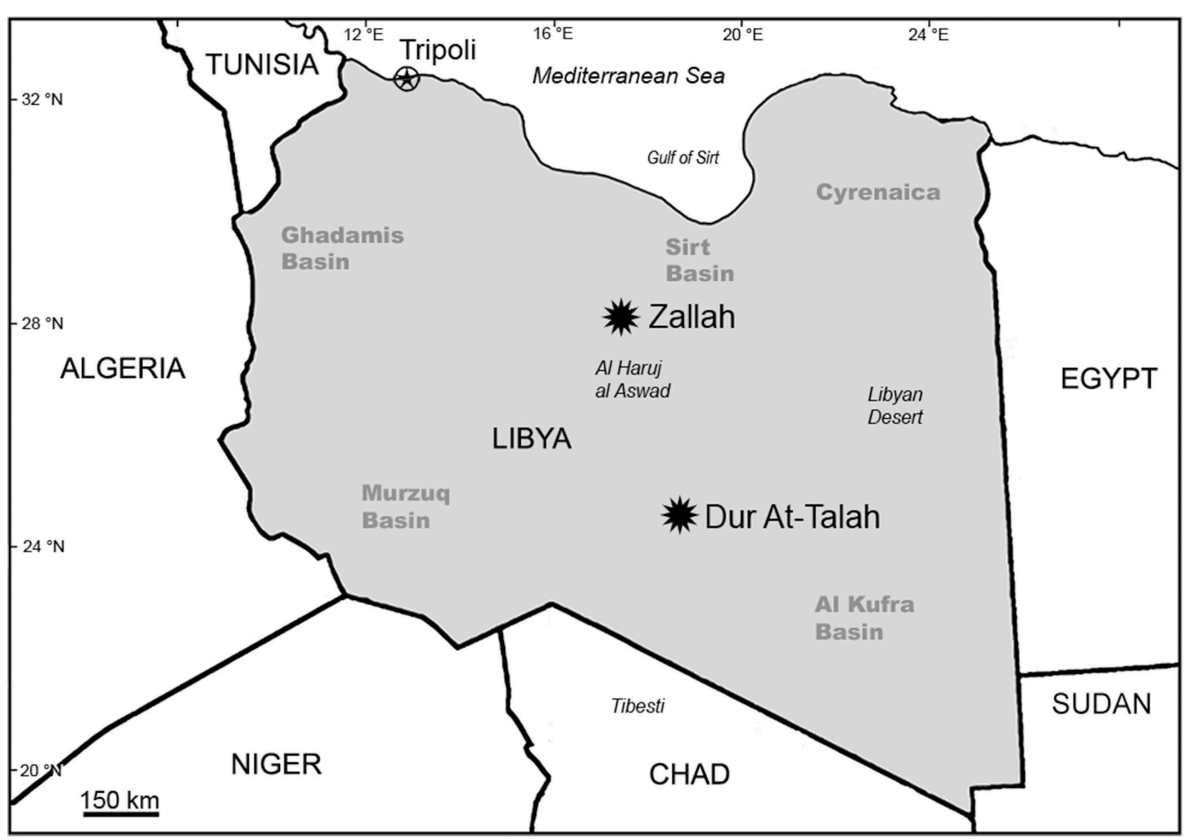

FIGURE 2 | Map of Libya and adjacent areas showing the location of Zallah Oasis and the Dur At-Talah escarpment in the Sirt Basin. 
and White, 1965; Savage, 1969; Court, 1995; Delmer, 2009; Jaeger et al., 2010a,b; Grohé et al., 2012; Tabuce et al., 2012). Fossil sites along the Dur At-Talah escarpment occur in strata showing normal magnetic polarity and appear to be latest middle Eocene in age (Jaeger et al., 2010a,b). A lens in the upper part of the New Idam Unit containing microvertebrate fossils, DT-Loc. 3, has yielded a new species of Nementchamyidae that we refer here to Kabirmys, a genus otherwise known only from the BQ-2 locality in the Fayum Depression, northern Egypt. The new species of Kabirmys from Dur At-Talah is one of the oldest anomaluroids currently known from Africa.

Fossil sites in the vicinity of Zallah Oasis occur in deltaic and fluvial strata in a unit that has been mapped as "Continental and Transitional Marine Deposits" or CTMD (Arambourg and Magnier, 1961; Arnould-Saget and Magnier, 1961; Arambourg, 1963; Vesely, 1985; Fejfar, 1987). These sites have traditionally been regarded as early Oligocene, an age determination that is strongly corroborated by our recent work in this rock unit (Coster et al., 2010, 2012, 2015). The recently discovered Zallah Incision local fauna, derived from the base of a fluvial channel within the CTMD, includes sirenians, anthracotheres, hyracoids, hystricognathous rodents and anthropoid primates (Beard et al., 2015a; Coster et al., 2015). Fossil mammal specimens currently known from the Zallah Incision local fauna span a wide range of sizes (from sirenian rib fragments and anthracothere cheek teeth to tiny rodent cheek teeth) and show little evidence of abrasion, suggesting minimal transport prior to deposition. Here we report an additional taxon from this locality, described below as a new genus and species of Anomaluridae. This new anomalurid is remarkably specialized for its age, differing little in its dental morphology from early Miocene and extant species that have been placed in the genus Zenkerella. So far, it represents the only evidence of Anomaluridae from the Oligocene of Africa.

Original fossil specimens described here are housed in the collections of the Geology Department of the Faculty of Science, University of Tripoli (Libya). High-resolution epoxy casts of the original specimens are housed in the collections of the Biodiversity Institute at the University of Kansas (USA) and in the collections of the Institut de Paléoprimatologie et Paléontologie humaine: Évolution et Paléoenvironnements at the Université de Poitiers (France). Dental terminology is depicted in Figure 3.

\section{Phylogenetic Methodology}

A parsimony analysis of dental features was undertaken in order to investigate the phylogenetic relationships of the new Libyan anomaluroids. We analyzed an updated version of the character-taxon matrix published by Marivaux et al. (2004), which is a comprehensive matrix including all major groups of Paleogene rodents. The data set includes 108 morphological (primarily dental) characters. The taxa sampled by Marivaux et al. (2004) were augmented by including all fossil anomaluroids, representatives of all three extant anomalurid genera, all Zegdoumyidae, and two fossil Pedetidae (see Supplementary Material). Multistate characters were treated as ordered if successive character states were hypothesized to correspond to a morphocline (see Supplementary Material). The Late Cretaceous
Upper tooth

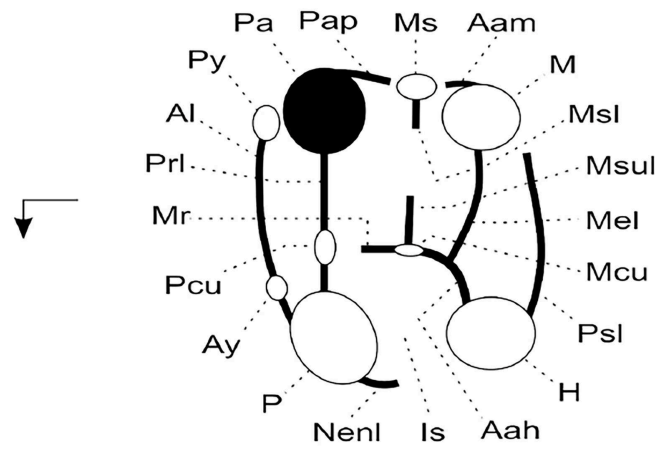

Lower tooth

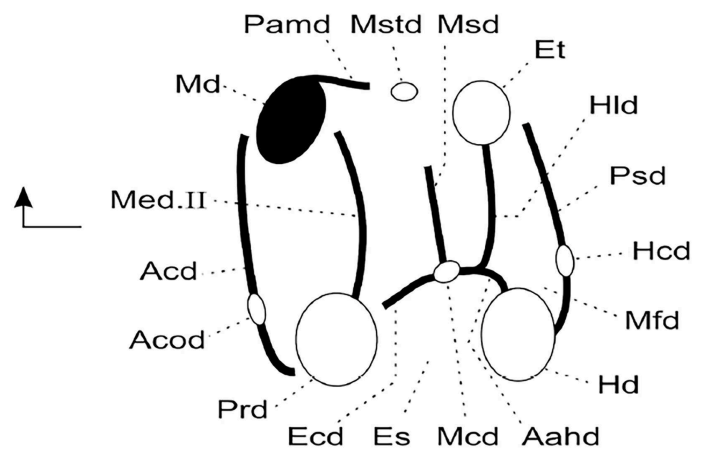

FIGURE 3 | Anatomical terminology used to describe rodent cheek teeth (adapted from Marivaux et al., 2011). Arrows point mesially and lingually to indicate orientation. Upper tooth abbreviations are as follows: Aah, anterior arm of hypocone; Aam, anterior arm of metacone; Al, anteroloph (or anterocingulum); Ay, anterostyle; $\mathrm{H}$, hypocone; Is, internal sinus; $\mathrm{M}$, metacone; Mcu, metaconule; Mel, metaloph; Mr, mure; Ms, mesostyle; Msl, mesoloph; Msul, mesolophule; Nenl, neo-endoloph; P, protocone; Pa, paracone; Pap, posterior arm of paracone; Pcu, protoconule; Prl, protoloph; Psl, posteroloph (or posterocingulum); Py, parastyle. Lower tooth abbreviations are as follows: Aahd, anterior arm of hypoconid; Acd, anterocingulid (or anterolophid); Acod, anteroconid; Ecd, ectolophid; Et, entoconid; Hcd, hypoconulid; Hd, hypoconid; HId, hypolophid; Es, external sinusid; Mcd, mesoconid; Md, metaconid; Med. II, metalophulid II (= protolophid or posterior arm of protoconid); Mfd, metafossettid; Msd, mesolophid; Mstd, mesostylid; Pamd, posterior arm of metaconid; Prd, protoconid; Psd, posterolophid.

and early Paleocene "condylarth" Protungulatum serves as the designated outgroup. The matrix was edited in Mesquite version 2.75 (Maddison and Maddison, 2015) and analyzed in TNT version 1.1 (Goloboff et al., 2008). Our search strategy was to analyze the data under the "New Technology search" option, selecting the sectorial search, ratchet and tree fusing search methods, all with default parameters. Under these settings, replications were run until the minimum length tree was found in 1000 separate replicates. The best trees obtained in this manner were subjected to a final round of TBR branch swapping.

Unconstrained analyses of the data matrix failed to support the monophyly of several widely recognized rodent clades, so we imposed a topological constraint requiring monophyly for three different clades: Ctenohystrica (hystricognathiforms 
and ctenodactyloids), a squirrel-related clade (sciuroids, aplodontoids and gliroids), and a mouse-related clade (muroids, dipodoids, geomyoids and castoroids) (see Supplementary Material).

\section{Results}

\section{Systematic Paleontology}

Class Mammalia Linnaeus, 1758

Order Rodentia Bowdich, 1821

Infraorder Anomaluromorpha Bugge, 1974

Superfamily Anomaluroidea Gervais, 1849

Family Nementchamyidae Jackson and Thorington, 2012

Genus Kabirmys Sallam et al., 2010b

Kabirmys prius, sp. nov.

Holotype-DT3-1, right $\mathrm{M}^{2}$ (length, $3.65 \mathrm{~mm}$; width, $4.01 \mathrm{~mm}$ ) (Figure 4).

Type locality-DT-Loc. 3, New Idam Unit of the Dur AtTalah escarpment, late middle Eocene of south-central Libya.

Etymology_Latin, prior, earlier or former.

Diagnosis-Large anomaluroid characterized by brachyodont and pentalophodont upper molar with an anteroloph, protoloph, mesolophule, metaloph and posteroloph. Upper molar with a rounded occlusal outline and concave occlusal surface, characterized by a high paracone, a main central protocone that extends toward a distally positioned hypocone, a strong oblique anterior arm of the hypocone and a Y-shape connection between the metaloph, the mesolophule and the anterior arm of the hypocone. Upper molar morphology differs from that of Kabirmys qarunensis in lacking a mure, having a long neoendoloph that closes the lingual sinus lingually, and having a smaller mesostyle.

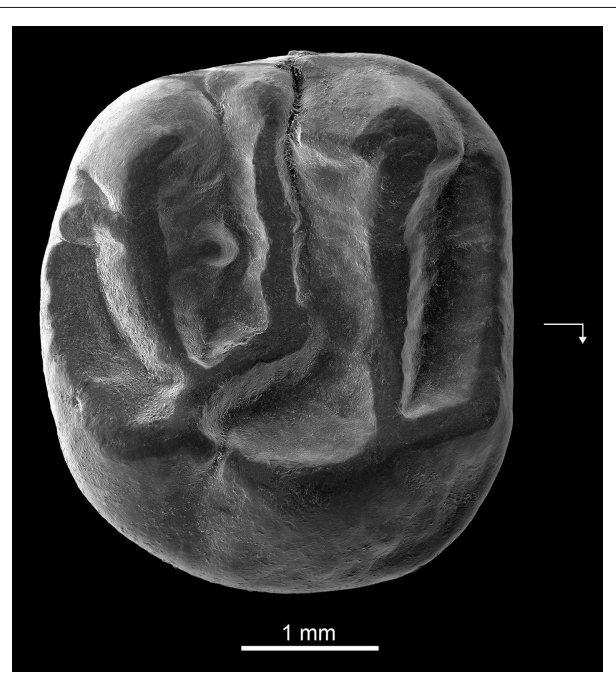

FIGURE 4 | Kabirmys prius, new species, DT3-1, New Idam Unit, late middle Eocene, Dur At-Talah escarpment, south-central Libya. Holotype right $\mathrm{M}^{2}$ in occlusal view. Arrow points mesially and lingually to indicate orientation.
Description-DT3-1 is a well-preserved right $\mathrm{M}^{2}$ (Figure 4). The tooth is almost circular in occlusal outline and displays a pentalophodont pattern with cusps still recognizable. The anteroloph is low, and it courses across the mesial margin of the tooth. It extends mesially from the protocone, connects to a distinct anterostyle and then turns buccally, ultimately joining a small parastyle on the mesiobuccal margin. The paracone is the highest cusp on the tooth; its anterior and posterior arms are relatively well developed. A faint mesiobuccal cingulum lines the base of the paracone. The protoloph is oriented parallel to the anteroloph. It runs transversely from the large and low protocone to fuse with the apex of the paracone. The protoloph is higher than the anteroloph and does not bear a protoconule. The protocone is a long crestiform cusp that is centrally located on the lingual side of the crown. The posterior part of the protocone extends distally toward the hypocone. The internal sinus remains slightly open lingually via a narrow notch. The hypocone has a more buccal position than the protocone and has a strong and elongated anterior arm. A small swelling at the mesial extremity of the anterior arm of the hypocone may correspond to a vestigial metaconule. The mesolophule courses bucally from the residual metaconule and merges with a distinct mesostyle. The mesotyle is stronger than the parastyle. A mure is absent, and the internal sinus is open bucally. The metaloph runs lingually from the metacone and curves slightly mesially to join the anterior arm of the hypocone. Two weak crenulations of the occlusal surface emanate from the metaloph. The posteroloph is low and courses around the distal margin of the tooth, extending bucally from the hypocone but without joining the metacone. There is no buccal wall per se; it is interrupted by narrow notches between the parastyle, the paracone, the mesostyle, and the metacone.

Comparison-The holotype upper molar of Kabirmys prius falls outside the range of metric variation documented by 22 upper molars of K. qarunensis from Egypt (Sallam et al., 2010b), being wider than any of the specimens of $K$. qarunensis described to date (Figure 5). Like $K$. qarunensis, $K$. prius exhibits a pentalophodont pattern of upper molar morphology with welldeveloped transverse lophs (Figure 6). Compared to Kabirmys prius, $K$. qarunensis has relatively stronger and more nearly continuous external crests that encircle the occlusal surface. The parastyle in K. qarunensis often joins the base of the paracone, and the mesostyle together with the posterior arm of the paracone and the anterior arm of the metacone forms a complete buccal wall. The buccal wall in Kabirmys prius is distinctly notched between the parastyle, paracone, mesostyle, and metacone (note that a buccal wall may develop as these cusps become worn with age). The upper molar morphology of K. qarunensis further differs in having a slightly larger mesostyle, a well-developed mure that runs longitudinally and closes the internal sinus buccally and in having the internal sinus more broadly open lingually. Although there is minor variation in these features within the sample of 22 upper molar specimens known for $K$. qarunensis (Sallam et al., 2010b: Figure 7), none approaches the conditions shown by the holotype of $K$. prius. Thus, the holotype of $K$. prius differs both qualitatively and metrically from the known sample of $K$. qarunensis. 


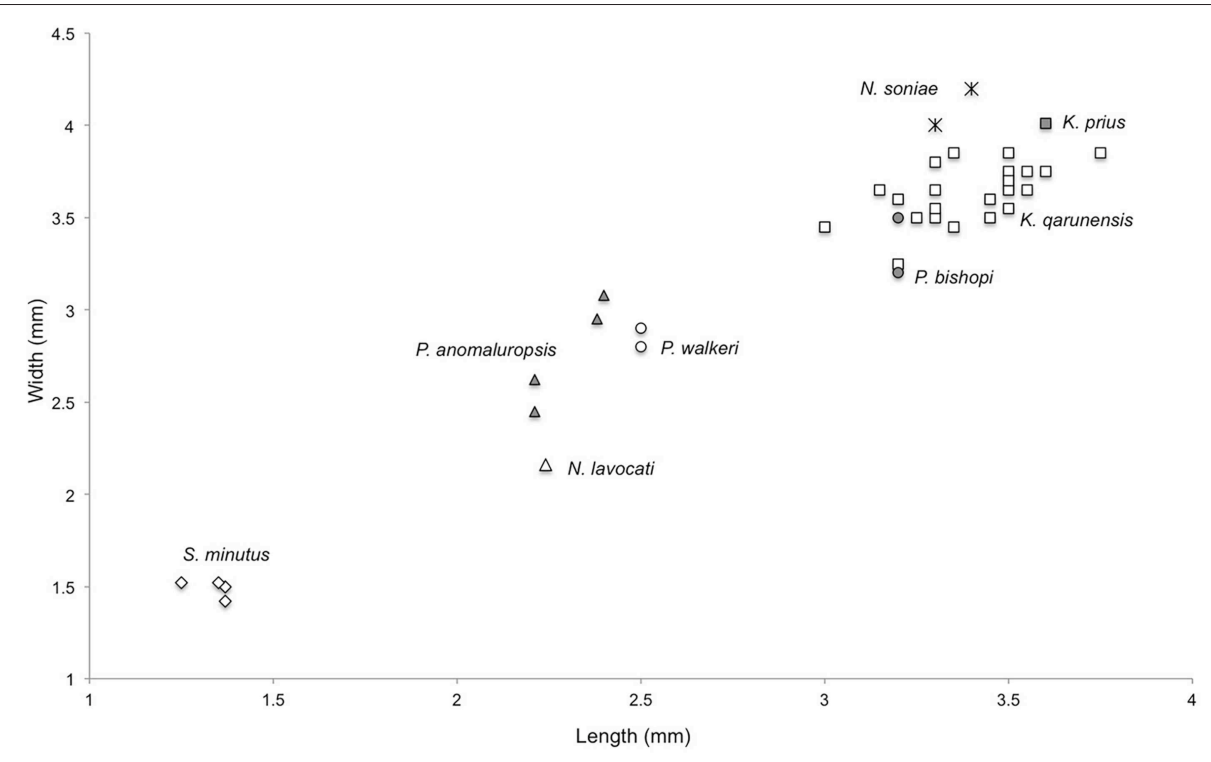

FIGURE 5 | Bivariate plot of length vs. width of $\mathbf{M}^{\mathbf{2}}$ among various fossil and extant anomaluroids. Symbols are as follows: Shazurus minutus, open diamonds; Pondaungimys anomaluropsis, closed triangles; Nementchamys lavocati, open triangle; Paranomalurus walkeri, open circles; Paranomalurus bishopi, closed circles; Nonanomalurus soniae, asterisks; Kabirmys qarunensis, open squares; Kabirmys prius, closed square.

Compared to the roughly contemporaneous Algerian and Burmese nementchamyid genera, $K$. prius lacks the heavy enamel crenulations that characterize the occlusal surfaces of upper molars of Nementchamys lavocati (Jaeger et al., 1985) and Pondaungimys anomaluropsis (Dawson et al., 2003; Marivaux et al., 2005). The upper molars of all three taxa display a similar basic pentalophodont pattern with a strong protoloph, relatively well developed anteroloph and posteroloph, a main central protocone that extends toward a very distally situated hypocone, a strong oblique anterior arm of the hypocone and buccal cusps separated by narrow notches. The mure is absent in both Kabirmys prius and Pondaungimys anomaluropsis, while it closes the internal sinus buccally in Nementchamys lavocati. The upper molar of $N$. lavocati differs from those of $P$. anomaluropsis and Kabirmys in having a supplementary crest running lingually from the parastyle, and in having two small cusps between the paracone and metacone, interpreted by Jaeger et al. (1985) as a double mesostyle. The presence of many enamel crenulations and small enamel accessory crests obscures the occlusal morphology of upper molars of $N$. lavocati (especially the configuration of the mesolophule and the metaloph), making further comparisons difficult. The upper molar morphology of $K$. prius further differs from that of $P$. anomaluropsis in lacking a residual protoconule and in having a single transverse mesolophule and a stronger connection between the lingual metaloph and the anterior arm of the hypocone.

The upper molar occlusal pattern of $K$. prius differs from that of fossil and extant anomalurid and nonanomalurid taxa in being less lophodont and in retaining better-defined cusps (Figure 6). The upper molars of Shazurus minutus (Sallam et al., 2010a) differ from that of Kabirmys prius in being much smaller and more rectangular in occlusal outline, in having a short accessory crest attached to the protoloph, in variably possessing a mure joining the mesolophule to the protoloph, and in having a complete wall of enamel surrounding the crown. The lingual wall runs mesiodistally to join the protocone to the hypocone, and the buccal cusps are fused together to form a longitudinal buccal wall. The mesolophule is variably developed, and the anterior arm of the hypocone of $S$. minutus is more transverse than that of Kabirmys prius. The upper molar morphology of early Miocene Paranomalurus (P. walkeri and P. bishopi; Lavocat, 1973) and extant Anomalurus differs from that of $K$. prius in being more nearly square or rectangular in occlusal outline, in having a more lophodont occlusal pattern, and in having a complete lingual wall. In P. walkeri, P. bishopi, and Anomalurus, the anterior arm of the hypocone is transversely oriented, while the anterior arm of the hypocone of Kabirmys has a more mesiobuccal orientation. In P. bishopi and Anomalurus the mesostyle is submerged into the buccal wall, while it merges with the posterior arm of the paracone in P. walkeri. In Paranomalurus and Anomalurus, the metacone and the paracone are strongly connected to the posteroloph and anteroloph, respectively.

Interestingly, the upper molars of Nonanomalurus soniae (Pickford et al., 2013) resemble the holotype of Kabirmys prius in having the buccal cusps still individualized and separated by narrow notches and in having a mesiobuccally oriented anterior arm of the hypocone. However, $N$. soniae lacks the connection between the metaloph and the anterior arm of the hypocone and mesolophule, and it has a more trenchant anteroloph and posteroloph, a relatively larger mesostyle and a smaller paracone than what is seen in K. prius.

The upper molar morphology of Kabirmys prius differs in many respects from that of Zegdoumyidae (Figure 6). The holotype of $K$. prius differs substantially from upper molars 


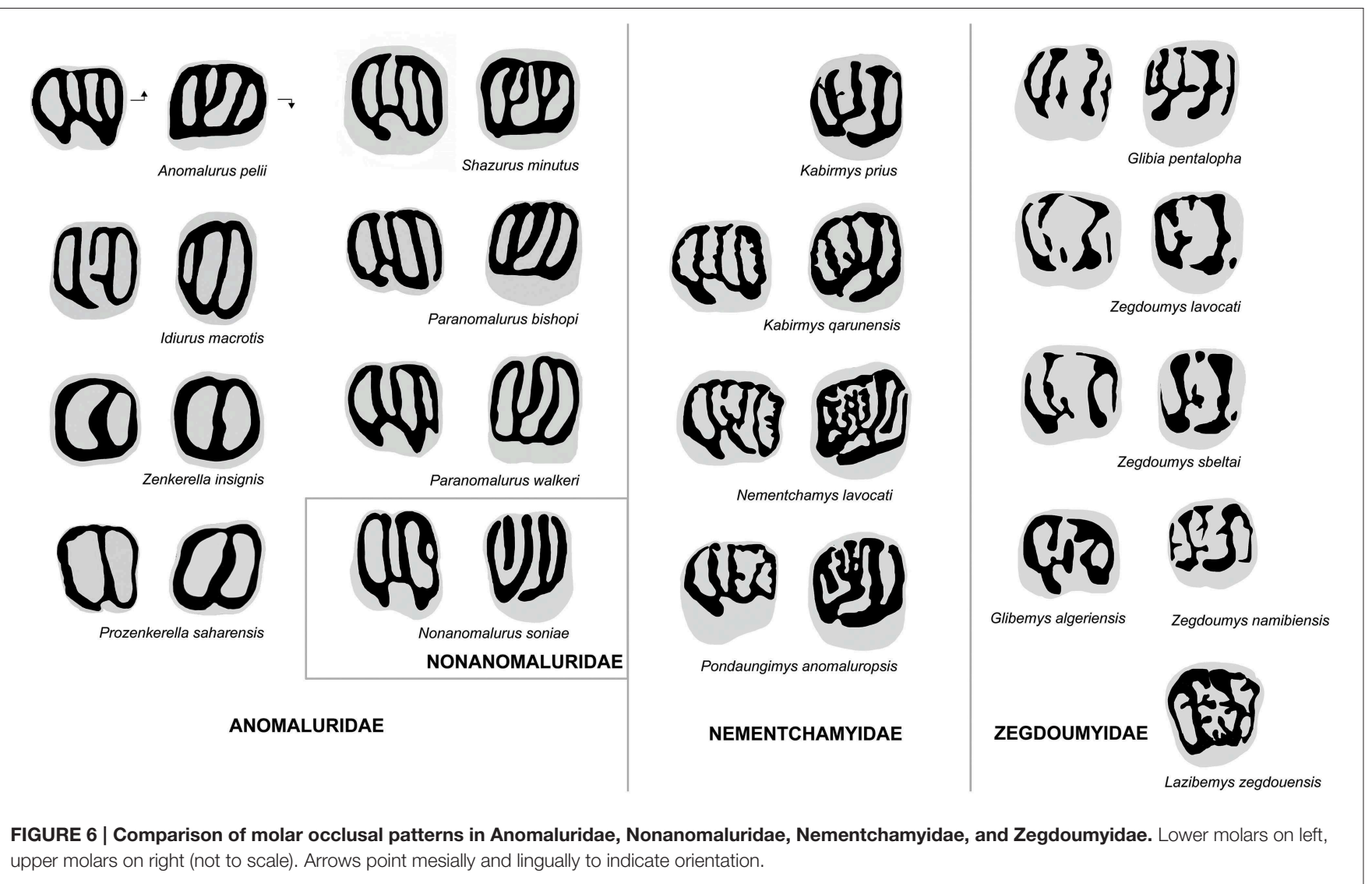

of Glibia pentalopha (Vianey-Liaud et al., 1994; Marivaux et al., 2011, 2015), in which the molars are much smaller and more bunodont, with rounded hypocone and protocone. The anteroloph and posteroloph in $K$. prius are much better developed than in $G$. pentalopha, in which these structures take the form of simple, low mesial and distal cingula. In contrast to $K$. prius, the upper molars of G. pentalopha exhibit a protoconule on the protoloph, an accessory conule on the distal cingulum, a reduced metacone, and a mesiodistally elongated metaconule that often joins the protoloph to form a complete mure. Glibia pentalopha further differs in lacking the anterostyle and the parastyle, in having a deeper and more transversely oriented internal sinus, a secondary connection of the metaloph to the posteroloph, and a thin crest of enamel that often connects the protoloph to the mesial cingulum. The mesolophule is variably developed in G. pentalopha, and the mesostyle is larger than that of $K$. prius.

The upper molar of Kabirmys prius differs from those of Zegdoumys (Z. lavocati, Z. sbeitlai, Vianey-Liaud et al., 1994; Z. namibiensis, Pickford et al., 2008) in being markedly larger and in exhibiting a pentalophodont pattern characterized by a well-developed anteroloph, mesolophule, and posteroloph with less bulbous cusps. The anteroloph in K. prius extends mesially from the protocone to join the small parastyle. In contrast, there is neither a parastyle nor an anteroloph in Zegdoumys, the latter structure having been replaced by a mesial cingulum that is isolated from the protocone. The protocone in K. prius constitutes a long crestiform cusp, and the hypocone is small and distally positioned. The lingual cusps in Zegdoumys are rounded and nearly equal in size. In K. prius, the protoloph forms a welldeveloped transverse crest that connects the mesial part of the protocone to the paracone, while the protoloph is interrupted near its midline by a protoconule in Zegdoumys sbeltai and $Z$. lavocati. Kabirmys prius further differs in having a notched buccal wall and a small, isolated mesostyle. In Z. lavocati, the mesostyle is mesiodistally elongated, connecting the metacone and the posterior arm of the paracone to form a nearly complete buccal wall. K. prius has a complete transverse metaloph running lingually from the metacone to join the anterior arm of the hypocone; the metaloph is discontinuous between the metacone and the metaconule in $Z$. lavocati. Z. namibiensis differs from Kabirmys prius in lacking the anterostyle and parastyle, in having a low anteroloph, a relatively weak mesolophule, and in having a strong mesostyle.

The presence of numerous enamel crenulations and complete lingual, distal, and buccal walls in Lazibemys zegdouensis (Marivaux et al., 2011) distinguishes the upper morphology of this taxon from that of Kabirmys prius. In contrast to that of $K$. prius, the upper molar of L. zegdouensis has a parastyle that is nearly as large as the paracone and a strong mesiodistally elongated mesostyle. Lazibemys zegdouensis further differs in having a paracone that is distally positioned with respect to the protocone, a mesial cingulum that is not connected lingually to the protocone, a posteroloph that connects the hypocone 
to the metacone, and in lacking a mesolophule. The upper molar morphology of L. zegdouensis shows a complex protoloph composed of short buccal and lingual crests emanating from the paracone and protocone, respectively. None of these lophs are transverse in orientation and parallel as they are in Kabirmys prius.

Family Anomaluridae Gervais, 1849

Subfamily Zenkerellinae Matschie, 1898

Genus Prozenkerella, gen. nov.

Type species-Prozenkerella saharaensis, only known species.

Etymology-Latin prefix pro- (before) + Zenkerella.

Diagnosis-Brachyodont cheek teeth with well-defined lophs and indistinct cusps. Differs from other anomaluroids in having simplified trilophodont teeth characterized by an enamel ring surrounding the crown and a central transverse ridge of enamel. Lower molars characterized by an anterolophid, a metalophulid II and a posterolophid, without mesolophid or hypolophid. Upper molars with an anteroloph, a protoloph and a posteroloph, lacking a mesolophule or a metaloph. Cheek teeth less rounded (more quadrate) in occlusal outline than in Zenkerella. Further differs from Zenkerella in having the buccal wall on the lower molars notched by an external sinusid (hypoflexid) delimited by the anterior arm of the hypoconid.

\section{Prozenkerella saharaensis, sp. nov.}

Holotype-Z7I-12, right lower molar (length, $1.64 \mathrm{~mm}$; width, $1.80 \mathrm{~mm}$ ) (Figure 7A).

Etymology-Refers to the provenance of this species.

Hypodigm - The holotype and Z7I-13, right upper molar (length, $1.46 \mathrm{~mm}$; width, $1.61 \mathrm{~mm}$ ) (Figure 7B).

Type locality-Zallah 7 Incision locality, Continental and Transitional Marine Deposits (CTMD), early Oligocene of central Libya (Coster et al., 2015).

Diagnosis-As for the genus.

Description-The lower molar (Figure 7A) is essentially trilophodont and subquadrate in occlusal outline. The anterolophid forms the mesial margin of the tooth. The protoconid and metaconid are crestiform and connected by a nearly transverse crest interpreted as being homologous with the metalophulid II. The anterolophid and metalophulid II isolate a shallow trigonid basin. The metaconid is more distal in position than the protoconid, so that the metalophulid II is oriented somewhat distolingually rather than transversely. The hypoconid and entoconid are also crestiform. There is neither a hypolophid nor a mesolophid. A low and short anterior arm of the hypoconid joins the buccal side of the metalophulid II, delimiting a deep yet narrow buccal sinusid. The posterolophid extends from the hypoconid toward the base of the entoconid on the distal margin of the tooth. There is no distinct hypoconulid. The posterior arm of the metaconid is high and connects to the anterior arm of the entoconid. The trigonid basin is slightly narrower mesiodistally than the talonid basin. The mesial, lingual and distal margins of the crown are surrounded by continuous enamel walls. The buccal wall is notched at the level of the external sinusid.

The upper molar (Figure 7B) also has a simplified trilophodont occlusal pattern. A complete wall of enamel

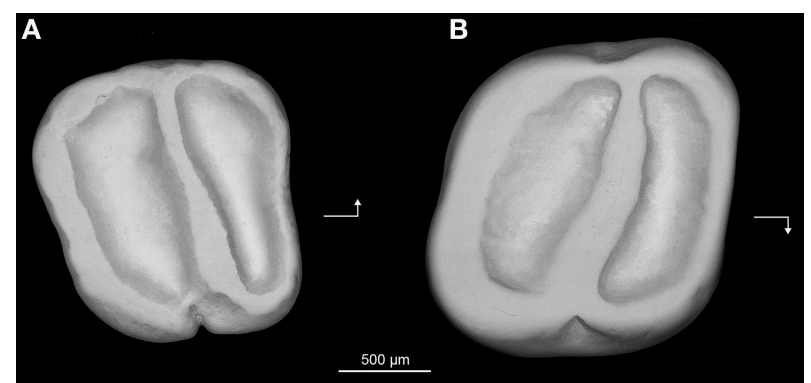

FIGURE 7 | Prozenkerella saharaensis, new genus and species, "Continental and Transitional Marine Deposits," early Oligocene, Zallah Incision local fauna, central Libya. (A) holotype right lower molar (Z7I-12) in occlusal view; (B) referred right upper molar (Z7I-13) in occlusal view. Arrows point mesially and lingually to indicate orientation.

surrounds the crown. The anteroloph delimits the mesial margin of the tooth, while the distal margin is defined by the posteroloph. The lingual wall is formed by a well-developed neo-endoloph. The anterior arm of the metacone is connected to the posterior arm of the paracone to form a buccal wall. The cusps are incorporated into the lophs, making it difficult to assess their relative positions. A single oblique crest extends buccally from the protocone, subdividing the central basin. This crest, interpreted here as the protoloph, has a slight mesiobuccaldistolingual orientation. The crown is slightly invaginated buccally and lingually at the level of the central crest.

Comparison-The simplified and derived morphology of the upper and lower dentition of Prozenkerella saharaensis is very similar to that Zenkerella wintoni from the early Miocene of Kenya (Lavocat, 1973) and Uganda (Pickford and Mein, 2006) and extant $Z$. insignis. $P$. saharaensis is slightly larger than $Z$. wintoni but slightly smaller than $Z$. insignis. P. saharaensis only differs from $Z$. insignis and $Z$. wintoni in some minor features mentioned previously in the diagnosis. The external crests that surround the occlusal surfaces of the lower and upper molars of $P$. saharaensis form a somewhat square outline, while these crests yield a more rounded occlusal outline in $Z$. insignis and Z. wintoni. The latter taxa lack the distinct anterior arm of the hypoconid that demarcates the external sinusid in $P$. saharaensis.

$P$. saharaensis, $Z$. wintoni, and $Z$. insignis share a highly derived molar morphology characterized by a simplified trilophodont pattern that is very different from that of other anomaluroids (Figure 6). The dental pattern of Zenkerella and Prozenkerella most closely resembles that of extant Idiurus, in which the dentition is characterized by a ring of enamel encircling the crown and two transverse crests subdividing the occlusal surface into three foveae. The upper molars of Prozenkerella, Zenkerella, and Idiurus share a continuous enamel wall surrounding the crown and an oblique protoloph. However, Idiurus differs in having upper molars that are relatively more transverse in outline and in having a third distal loph corresponding to a metaloph. In early stages of wear, the buccal and lingual walls of upper molars of Idiurus are not entirely closed but notched in front of the hypocone and metacone, respectively. On the lowers, Prozenkerella and Zenkerella lack 
the hypolophid that is retained in Idiurus. The mesolophid is variably developed in Idiurus macrotis and is lacking in Idiurus zenkeri. In Idiurus the anterior arm of the hypoconid is connected to the hypolophid and the ectolophid is lacking. In contrast to Prozenkerella saharaensis, the hypoflexid is open and the lingual wall is not completely closed, being notched in front of the entoconid.

\section{Phylogenetic Analyses}

The results of our phylogenetic analyses (Figure 8) consistently support the monophyly of a large Anomaluroidea clade, including Paleogene (Pondaungimys, Nementchamys, Kabirmys, Shazurus, Downsimys, and Prozenkerella) and Neogene (Nonanomalurus and Paranomalurus) anomaluroid taxa as well as the extant Anomaluridae (Anomalurus, Idiurus, and Zenkerella). The late middle-early late Eocene nementchamyids (Pondaungimys, Nementchamys, and Kabirmys) form a clade that comprises the sister group to all other living and extinct anomaluroids. Although nementchamyids are characterized by the retention of several plesiomorphic anomaluroid features, they share several derived dental characters with fossil and extant anomalurids (on the upper molars, these include the development of a neo-endoloph and a buccal wall, a large mesostyle, a strong anterostyle, and a Y-shaped connection between the mesolophule, the metaloph and the anterior arm of the hypocone; on the lower molars, these include the absence of a metalophulid I and a hypoconulid, and the development of a strong anterolophid and mesolophid). The crenulated enamel found in Pondaungimys and (especially) Nementchamys diverges from the standard pentalophodont pattern found in more advanced anomaluroids (Jaeger et al., 1985), but this feature may be an autapomorphic condition within nementchamyids.

Kabirmys prius from Libya appears to be closely related to $K$. qarunensis from Egypt. The Egyptian and Libyan species of Kabirmys form the sister group of a clade including Pondaungimys anomaluropsis and Nementchamys lavocati (Figure 9). K. prius has a more plesiomorphic dental pattern than that of $K$. qarunensis, which is characterized by a stronger mesostyle, a better-developed buccal wall, a well-developed mure, and a reduced neo-endoloph that fails to close the internal sinus lingually. Pondaungimys anomaluropsis is most similar to Nementchamys lavocati, but Asian Pondaungimys has a dental pattern that is more plesiomorphic in some respects than that of any African nementchamyid. The upper molars of Pondaungimys bear many derived features that have been mentioned above as evidence for a relationship between nementchamyids and anomaluroids. However, numerous plesiomorphic features, such as the retention of a metaconule and protoconule, a non-linear mesolophule, an incomplete buccal wall, a small mesostyle, and a weak or incomplete connection between the metaloph, the mesolophule and the anterior arm of the hypocone, all mark the upper molars of Pondaungimys as those of a very primitive anomaluroid. The lower dentition of Pondaungimys also retains such plesiomorphic features as a poorly developed metalophulid II and a weak lingual wall.

The early Miocene species Nonanomalurus soniae, recently allocated to the new family Nonanomaluridae by Pickford et al. (2013), is reconstructed as the sister group of Anomaluridae

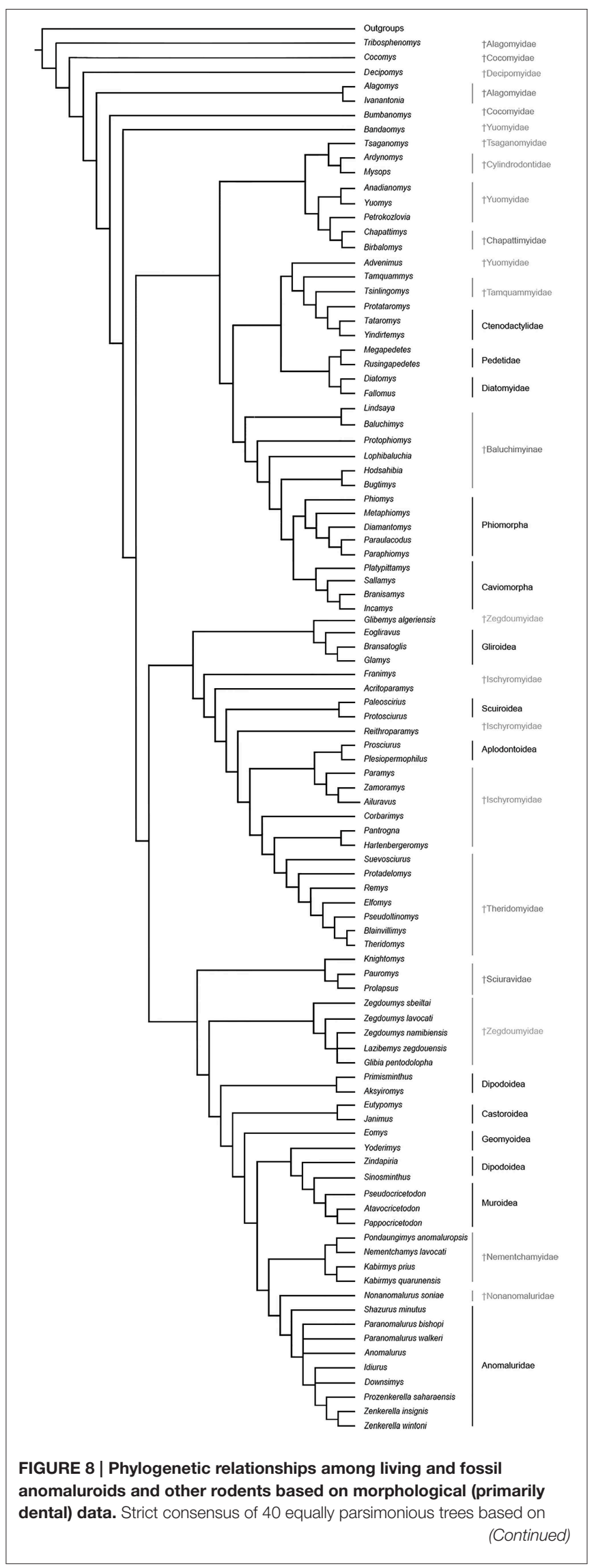




\section{FIGURE 8 | Continued}

a parsimony analysis of a modified version of the character-taxon matrix of Marivaux et al. (2004) with topological constraint requiring monophyly for Ctenohystrica (hystricognathiforms and ctenodactyloids), a squirrel-related clade (sciuroids, aplodontoids, gliroids), and a mouse-related clade (muroids, dipodoids, geomyoids and castoroids) (see Supplementary Information). Tree length, 1385; consistency index, 0.145; retention index, 0.677 (sensu stricto) (Figure 9). The cheek teeth of N. soniae share some derived features with those of anomalurids but differ in that the metaloph on the upper molars fails to join the anterior arm of the hypocone and mesolophule lingually, the buccal cusps on upper molars remain individualized and separated by narrow notches, and the metalophulid II on lower molars is partly fused with the anterolophid. N. soniae shares with Kabirmys qarunensis the presence of a short neo-endoloph, which is not a characteristic feature for anomalurids.

The early late Eocene Shazurus minutus is the oldest member of Anomaluridae discovered to date, and it appears to be the sister group of all other anomalurids (Figure 9). It is most similar in dental morphology to early Miocene Paranomalurus and extant Anomalurus. Relationships among anomalurids other than Shazurus are poorly resolved at present, forming a basal polytomy that includes both species currently assigned to Paranomalurus, extant Anomalurus, and a clade including Downsimys, Idiurus, Prozenkerella, and Zenkerella. Prozenkerella from the early Oligocene of Libya is the oldest known member of the crown clade Anomaluridae, being reconstructed as the sister group of a clade including early Miocene Zenkerella wintoni and extant Z. insignis.

Zegdoumyids, which are the oldest known family of rodents in Africa, were previously identified as a possible stem group for Anomaluridae (Vianey-Liaud et al., 1994; Vianey-Liaud and Jaeger, 1996; Marivaux et al., 2011, 2015). Reflecting fundamental differences in their dental morphology, our phylogenetic analyses fail to support a special relationship between zegdoumyids and anomaluroids (Figure 8). The early stages of pentalophodonty in Glibia, the complexity of enamel wrinkles in Lazibemys, and the development of a lingual wall on the lower molars of Zegdoumys and Glibemys are indeed anomaluroid-like characters. However, zegdoumyids are more derived than anomaluroids in having lower molars characterized by the absence of a complete ectolophid, loss of the hypoconulid, and development of a transversely elongated mesoconid. Among known zegdoumyids, Glibia pentalopha most resembles anomaluroids in developing transverse lophs on its upper and lower molars, but Glibia differs from anomaluroids in having upper molars with a reduced metacone, a posteroconule on the distal cingulum, and a secondary connection between the metaloph and the distal cingulum. The lower molars of Glibia differ from those of anomaluroids in having the buccal part of the hypolophid being oriented distally. Moreover, lower molars of Glibia, Zegdoumys, and Glibemys display a strong metalophulid II and a low anterocingulid, whereas the anterolophid is stronger than the metalophulid II in primitive anomaluroids. In our phylogenetic analysis (Figure 8), the Sciuravidae and most
Zegdoumyidae (including Zegdoumys, Lazibemys, and Glibia) are successive sister groups to a large "mouse-related clade" including Muroidea, Dipodoidea, Geomyoidea, Castoroidea, and Anomaluroidea. The traditional concept of Zegdoumyidae appears to be diphyletic, because Glibemys algeriensis, which is only documented by a single tooth, is recovered as a basal gliroid in our analysis.

\section{Discussion}

\section{Origin and Early Evolution of Anomaluroidea}

Rather than being derived from earlier Eocene African rodents belonging to the zegdoumyid radiation, our phylogenetic analyses suggest that anomaluroids are more closely related to primitive Myodonta, Castoroidea, and Geomyoidea. This finding has implications for both the timing and biogeography of early anomaluroid evolution. The earliest known fossil representative of the Myodonta is Erlianomys combinatus from the Arshanto Formation in Inner Mongolia, which is regarded as middle-late Ypresian in age (Li, 2015). Cladogenesis between Myodonta and Anomaluroidea must have occurred prior to this time, suggesting that Anomaluroidea (or Anomaluromorpha; see below) may have originated sometime during the late Paleocene or early Eocene. If so, anomaluroids have a very long ghost lineage, and this missing early component of their fossil record has complicated efforts to clarify their phylogenetic relationships, especially on the basis of morphological data alone. Biogeographically, it must be emphasized that all early members of the myodont, castoroid, and geomyoid clades were restricted to Laurasian distributions during the Paleogene, while zegdoumyids are known only from Africa. Hence, if our phylogenetic results are broadly correct, a northern (most likely Asian) origin for Anomaluroidea would be expected. Indeed, an Asian origin for Anomaluroidea is already supported by the antiquity of the nementchamyid Pondaungimys from the late middle Eocene Pondaung Formation of Myanmar, which is the earliest known record for Anomaluroidea (Dawson et al., 2003; Marivaux et al., 2005).

In agreement with their stratigraphic range and plesiomorphic dental morphology, nementchamyids appear to be the most basal anomaluroid group documented in the fossil record so far (Figure 9). In this respect, our phylogenetic results conflict with those reported by Sallam et al. (2010a,b), whose analyses of morphological data suggested that nementchamyids are deeply nested within crown clade anomalurids (as the sister group of Anomalurus) (e.g., Sallam et al., 2010b: Figure 9A). Sallam et al. (2010a,b) found that alternative phylogenetic analyses incorporating a chronobiogeographic character yielded tree topologies that more closely approximate our results based on morphology alone, although nementchamyids were reconstructed as a paraphyletic assemblage of basal anomaluroids rather than a basal clade via this procedure (e.g., Sallam et al., 2010b: Figures 9B,C). Marivaux et al. (2011, 2015) also recovered Nementchamyidae as a relatively basal anomaluroid clade, although Marivaux et al. (2015: Figure 5) found early Miocene Nonanomalurus to be even more basal than Nementchamyidae. 


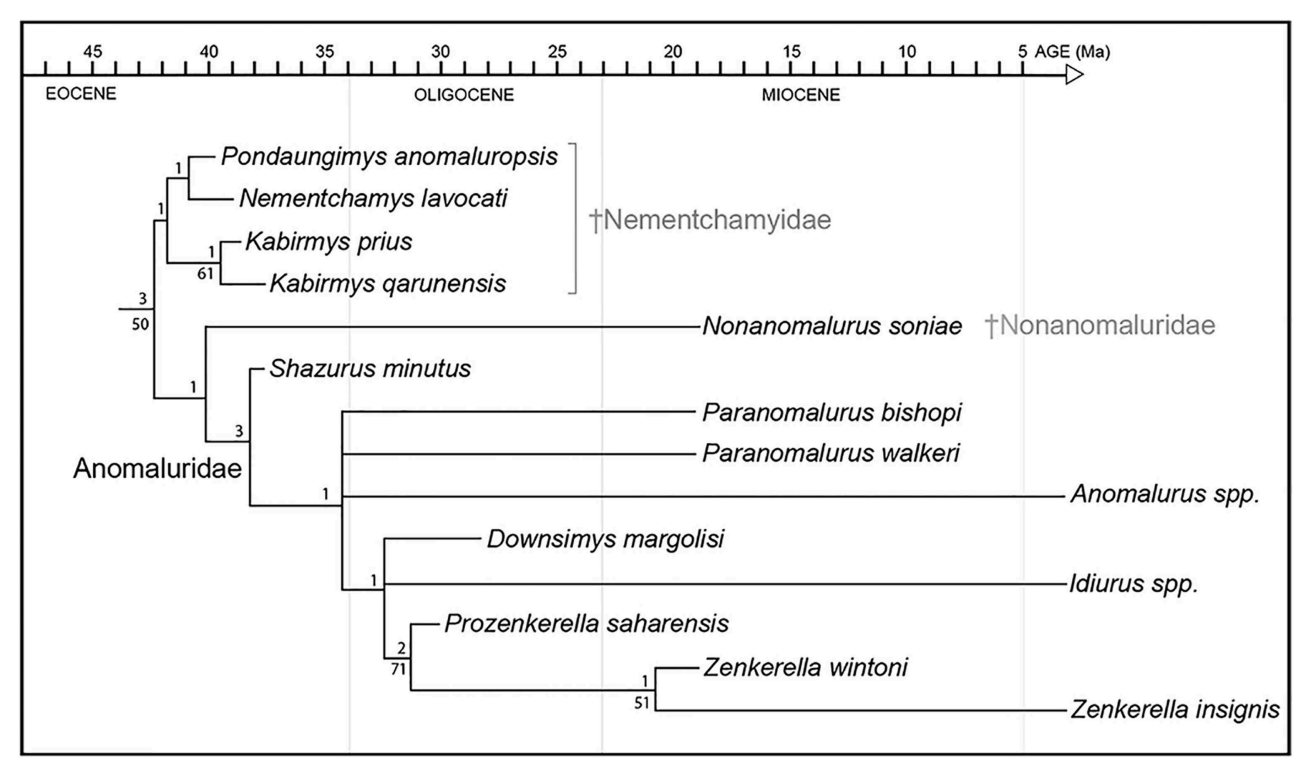

FIGURE 9 | Phylogenetic relationships among living and fossil anomaluroids incorporating stratigraphic range data for fossil forms. Approximate geochronological age of fossil taxa equals the youngest point on the line leading to individual taxa (older segments represent ghost lineages required by the tree topology shown here and the stratigraphic ranges of closely related taxa). Ghost lineages should not be confused with calibrated molecular divergence dates. For example, while Idiurus and Zenkerella must have diverged by the early Oligocene according to these results, this is a minimum estimate based on the age and inferred relationships of Prozenkerella. Relative stability of individual clades was assessed using bootstrap (Felsenstein, 1985) and Bremer support (Bremer, 1994) analyses. Bootstrapping was based on 1000 replicates. Bootstrap values $>50 \%$ are shown below branches. Bremer support is given above branches.

Once anomaluroids appear in the fossil record, they are morphologically distinctive, at least with respect to their dentition (Figure 6). The extent to which this distinctive anomaluroid morphology extends to other anatomical regions remains to be determined, because nementchamyid skulls and postcranial elements have yet to be formally described. Some postcranial elements are known for Kabirmys qarunensis, and preliminary assessment of the postcranial anatomy of $K$. qarunensis suggests that this taxon retains many plesiomorphic postcranial traits that diverge from conditions found in crown clade anomalurids (Sallam et al., 2010c). If this pattern is borne out by more detailed descriptions and analyses, the primitive postcranial anatomy of $K$. qarunensis would conflict with phylogenetic reconstructions that interpret this taxon as being nested within crown clade anomalurids (cf. Sallam et al., 2010a,b).

Based on our phylogenetic results and the stratigraphic distribution of key fossil taxa, all three anomaluroid families seem to have been established prior to the end of the Eocene. Nementchamyids are now recorded at three penecontemporaneous North African sites lying near the middle-late Eocene boundary (Bir el Ater in Algeria, Dur At-Talah in Libya, and the BQ-2 locality in Fayum, Egypt). Additionally, the basal anomalurid Shazurus occurs at BQ-2 in Egypt (Sallam et al., 2010a). Although nonanomalurids do not appear in the fossil record until the early Miocene, their inferred phylogenetic relationships-either as the sister group of anomalurids (Figure 9) or as the sister group of all other anomaluroids (Marivaux et al., 2015)-imply that they have a ghost lineage extending back to the middle-late Eocene boundary.

The discovery of Prozenkerella saharaensis in the early Oligocene of central Libya stands as the oldest current record for the crown clade Anomaluridae. Prozenkerella extends the stratigraphic range of Zenkerellinae from the early Miocene $(\sim 17$ $\mathrm{Ma})$ to the early Oligocene ( $\sim 31 \mathrm{Ma})$, an interval of roughly 14 Ma. Assuming that Prozenkerella is the sister group of living and fossil species of Zenkerella (Figure 9), it implies that the three extant anomalurid genera (Zenkerella, Idiurus, and Anomalurus) diverged prior to the early Oligocene, which is consistent with molecular divergence estimates that place the split between Anomalurinae and Zenkerellinae during the Eocene (Montgelard et al., 2008). The topology of our phylogenetic tree (Figure 9) suggests long ghost lineages for both Idiurus and Anomalurus. So far, the oldest known Anomalurus dates to the middle Miocene (Winkler, 1992), whereas fossil representatives of Idiurus have yet to be described.

How do our phylogenetic results based on morphological data compare with tree topologies of living rodents derived from phylogenetic analyses of molecular data? In agreement with many recent molecular analyses of rodent phylogeny, our results suggest that anomaluroids are closely related to the myodont clade. However, our analyses fail to support a clade containing Pedetidae and Anomaluroidea (Anomaluromorpha), although this grouping is frequently recovered by phylogenetic analyses of genomic data (Montgelard et al., 2002, 2008; BlangaKanfi et al., 2009; Churakov et al., 2010; Fabre et al., 2012). Anomaluromorpha is also supported by certain morphological 
data, particularly patterns of cranial arterial circulation and middle ear anatomy (Gill, 1872; Bugge, 1974; Lavocat and Parent, 1985; Ruf et al., 2010; Marivaux et al., 2011). The two crown clades included in Anomaluromorpha (Pedetidae and Anomaluridae) are highly autapomorphous and morphologically divergent from one another, particularly with respect to their postcranial skeletons and dentitions. One suite of characters that is often regarded as having high phylogenetic valence among rodents is the microstructure or Schmelzmuster of incisor enamel. Nementchamyid incisors show a Schmelzmuster that is transitional from the plesiomorphic pauciserial to the derived uniserial condition (Marivaux et al., 2005), while pedetids exhibit the alternately derived multiserial condition that also occurs in Ctenohystrica (Martin, 1993, 1995). Hence, it seems unlikely that pedetids could have evolved from a nementchamyid-like form. Pedetids differ from all living and fossil anomaluroids in having bilophodont cheek teeth that more closely resemble those of diatomyids (Dawson et al., 2006, 2010). From a paleontological perspective, the only way to test the monophyly of Anomaluromorpha and to determine how pedetids are related to living and fossil anomaluroids is to recover older and significantly more primitive fossil pedetids.

Unfortunately, the fossil record of Pedetidae fails to clarify their potential relationships with early anomaluroids. The oldest known pedetids have been reported from the early Miocene of Kenya and Uganda, and these taxa are already highly specialized (Lavocat, 1973; Pickford and Mein, 2011). Given that the oldest anomaluroids are found in Asia, it is possible that the divergence between pedetids and anomaluroids occurred on that continent and that stem pedetids trace back to Asia instead of Africa. The occurrence of highly specialized anomalurids by the late Eocene and early Oligocene (i.e., Shazurus, Prozenkerella) and similarly specialized pedetids by the early Miocene suggests that these two groups must have diverged relatively early in the Paleogene. This is generally consistent with molecular estimates of the divergence between anomalurids and pedetids, which often extend back to the Paleocene (Huchon et al., 2007; Montgelard et al., 2008).

\section{Evolution of Gliding in Anomaluridae}

Gliding locomotion is an uncommon adaptation among living mammals, but at least six modern mammal clades appear to have evolved the capacity to glide independently (Thorington, 1984; Jackson, 2000; Byrnes and Spence, 2011). In contrast to flying squirrels (Petauristinae) and colugos or flying lemurs (Dermoptera), the crown clade Anomaluridae is unique among living placental mammals in that it includes both gliding (Anomalurus and Idiurus) and non-gliding (Zenkerella) forms. As noted by Thorington (1984), each clade of extant gliding mammals shows a taxon-specific mode of attaching the patagium or gliding membrane to the forelimb. Gliding anomalurids have evolved a neomorphic cartilaginous rod, which attaches to the olecranon process of the proximal ulna in the elbow region, as a structural support for the leading edge of the patagium (Figure 1D). Osteologically, this cartilaginous rod articulates with an expanded bony process or flange located on the proximal ulnar shaft, opposite the semilunar notch for articulation with the distal humerus (Figure 1E). Both of the modern gliding anomalurid genera (Anomalurus and Idiurus) have an expanded bony flange or process on their olecranon to accommodate the styliform cartilage that supports the patagium, while the nongliding genus Zenkerella lacks these features (Figures 1D-F).

Turning now to the fossil record, Lavocat (1973) and Pickford et al. (2013) have described proximal ulnar fragments from the early Miocene of Kenya and Uganda that also bear expanded flanges on their olecranons. Based on their size, morphology and provenance, Pickford et al. (2013) refer these ulnar fragments to Paranomalurus bishopi and P. walkeri. Both Lavocat (1973) and Pickford et al. (2013) concur in interpreting the expanded olecranon flanges on these ulnar fragments as evidence that anomalurid-like gliding adaptations had evolved in Paranomalurus by the early Miocene. In contrast, a partly articulated skeleton of early Miocene Nonanomalurus soniae from the early Miocene of Uganda lacks an expanded bony flange on its olecranon process, nor does it bear any other evidence for gliding locomotion (Pickford et al., 2013). As noted previously, undescribed specimens attributed to the late Eocene nementchamyid Kabirmys qarunensis have also been reported to lack an expanded bony flange on the olecranon (Sallam et al., 2010c). Hence, available evidence suggests that both of the potential outgroups to Anomaluridae (Nementchamyidae and Nonanomaluridae) lacked the neomorphic styliform cartilage that supports the leading edge of the patagium in those modern anomalurids that are capable of gliding. In other words, basal anomaluroid taxa such as nementchamyids and nonanomalurids were non-gliding rodents, which would thus be the primitive condition among Anomaluroidea as a whole.

Reconstructing the evolution of gliding among crown clade Anomaluridae is not straightforward, however. Traditionally, extant anomalurids have been segregated into the subfamilies Anomalurinae (Anomalurus) and Zenkerellinae (Zenkerella and Idiurus), primarily on the basis of craniodental morphology (Wilson and Reeder, 2005; Happold, 2013). For example, Zenkerella and Idiurus share a more simplified pattern of cheek tooth morphology than that of Anomalurus (Figure 6). On the other hand, both Anomalurus and Idiurus can glide, and their patagia are supported by neomorphic cartilaginous rods that attach to bony flanges or processes on the olecranon process of the ulna (Figures 1D,E). Zenkerella cannot glide, has neither a patagium nor a styliform cartilage, and lacks a bony flange or process on its olecranon (Figure 1F).

If we assume that the traditional systematic arrangement of living anomalurid genera reflects phylogenetic reality, we are compelled to conclude either that the gliding adaptations that appear to be homologous in Anomalurus and Idiurus arose convergently (Figure 1A) or that Zenkerella has secondarily lost the ability to glide along with any osteological traces of having once had a gliding ancestry (Figure 1B). Given what we know about the postcranial anatomy of living and fossil anomalurids, we find either or these possibilities to be unlikely. An alternative hypothesis that now warrants closer scrutiny is that the traditional systematic arrangement of living anomalurids is incorrect, and that non-volant Zenkerella is actually the sister group of a volant anomalurid clade including extant Anomalurus and Idiurus as well as early Miocene Paranomalurus 
(Figure 1C). Significantly, the phylogenetic relationships among living anomalurid genera have yet to be explored on the basis of modern molecular techniques, because nucleotide sequence data are lacking for Zenkerella, which is extremely rare in museum collections worldwide.

\section{Relative Age and Paleoenvironments of Paleogene Sites in North Africa Bearing Anomaluroid Rodents}

The oldest African anomaluroid rodents are found alongside the oldest African hystricognathous rodents and anthropoid primates at three penecontemporaneous Eocene sites: Bir el Ater in northeastern Algeria (Jaeger et al., 1985), BQ-2 in Fayum, northern Egypt (Sallam et al., 2010a,b) and Dur At-Talah in south-central Libya (this paper). Partly because these sites have yielded the oldest known African anthropoids, their relative ages have proven to be controversial. Jaeger et al. (2010a,b) suggested that the mammalian fauna from Dur At-Talah in Libya is likely to be close in age to that from Bir el Ater in Algeria, based on the common occurrence of the parapithecid primate Biretia piveteaui and similarities observed in the hystricognathous rodent and proboscidean assemblages from both sites. The early late Eocene site of BQ-2 in Fayum, Egypt was considered to be slightly younger than either Bir el Ater or Dur At-Talah by Jaeger et al. (2010a,b). Primarily on the basis of the fossil rodent assemblages known at that time from these three North African sites, Sallam et al. (2012) disputed the correlation proposed by Jaeger et al. (2010a,b). Instead, Sallam et al. (2012) suggested that Dur AtTalah was younger than Bir el Ater and BQ-2, preferring a correlation with the middle part of the late Eocene for the Libyan sites along the Dur At-Talah escarpment. Part of the rationale cited by Sallam et al. (2012) for interpreting Dur At-Talah as being younger than either Bir el Ater or BQ-2 was the apparent absence of anomaluroid rodents from Dur At-Talah.

Our description of Kabirmys prius from Dur At-Talah obviously removes this particular criterion from further efforts to correlate Dur At-Talah with sites of similar age in Algeria and Egypt. In fact, closer comparisons between Kabirmys prius from Dur At-Talah and Kabirmys qarunensis from BQ-2 reveal the Libyan species to be more plesiomorphic. The upper molar morphology of $K$. prius from Libya is intermediate between those of K. qarunensis (early late Eocene, Egypt) and Pondaungimys anomaluropsis (late middle Eocene, Myanmar) in lacking a mure, lacking a relatively complete buccal wall, and lacking a relatively open lingual sinus (Figure 6). We acknowledge that having relatively primitive anatomy does not always make a given fossil older than its close relatives, but similar assessment of the "stage of evolution" of the hystricognathous rodents from Dur At-Talah and BQ-2 was the primary reason Sallam et al. (2012) regarded Dur at-Talah as being younger than the Egyptian site in the first place. Without additional geochronological control, we regard Dur At-Talah, Bir el Ater and BQ-2 as being penecontemporaenous, all lying near the middle-late Eocene boundary.

The unexpected discovery of the anomalurid Prozenkerella as part of the early Oligocene Zallah Incision local fauna underscores the disparity between this Libyan fauna and closely correlative faunas known from the Jebel Qatrani Formation in the Fayum Depression, Egypt (Coster et al., 2015; Beard et al., 2015a,b). Sallam et al. (2010a,b) emphasized that, while two taxa of anomaluroids are known from the early late Eocene BQ-2 site in the Fayum, none has ever been recorded from younger Eocene and Oligocene sites there, despite intensive collecting efforts over a period of several decades. In contrast, we recovered Prozenkerella during a fairly brief reconnaissance survey of early Oligocene CTMD rocks exposed near Zallah in January 2013 (Coster et al., 2015). Elsewhere in Afro-Arabia, early Oligocene anomalurids have been reported, but not yet described, from the Taqah local fauna in Oman (Thomas et al., 1999). Whether the patchy distribution of early Oligocene anomalurids currently documented across the northern part of Afro-Arabia accurately reflects their ancient geographic range as opposed to such potentially confounding factors as collecting bias or taphonomy is not completely clear. Rarely is this ever the case with the fossil record. However, the vastly different amounts of time and effort that have gone into collecting the early Oligocene mammal faunas of Egypt and Libya weigh heavily in favor of viewing the documented distribution of Oligocene anomalurids as real, rather than some artifact caused by the vagaries of the fossil record.

Although their Paleogene record remains rather poor, current knowledge of the distribution of Afro-Arabian anomaluroid rodents across the Eocene-Oligocene boundary reveals an interesting pattern. During the latter part of the Eocene, anomaluroids are recorded at all three major sites of this age in northern Africa, from Bir el Ater in the west to Fayum in the east. During the cooler and drier climatic regime of the early Oligocene, anomaluroids seem to have gone locally extinct in the Fayum region of Egypt (Sallam et al., 2010a,b), while these animals persisted in central Libya and Oman. Beard et al. (2015a,b) have suggested that the cooler, drier climatic conditions of the early Oligocene may have led to more heterogeneous or fragmented environments, resulting in geographic barriers to gene flow among widely distributed populations of primates and other arboreal mammals. Stronger geographic differences in faunal composition during the early Oligocene than during the preceding Eocene, as documented here for anomaluroid rodents, are to be expected under this hypothesis. In any case, Prozenkerella demonstrates that crown clade anomalurids ranged far beyond their current distribution in western and central Africa as recently as the late Paleogene.

\section{Author Contributions}

All authors contributed to the conception and design of this research, data acquisition, and analysis. All authors contributed to drafts of this paper including the final draft for submission. All authors agree to be accountable for all aspects of the work, including accuracy.

\section{Acknowledgments}

We thank Mouloud Benammi, Xavier Valentin and Olivier Chavasseau (Université de Poitiers), who participated in the 
fieldwork at Dur At-Talah that led to the discovery of Kabirmys prius. Fieldwork leading to the discovery of the Zallah Incision local fauna and Prozenkerella saharaensis would not have been possible without the extraordinary logistical support that was provided by personnel from Zuetina Oil Company in Libya. Christiane Funk (Museum für Naturkunde, Berlin), Ross D. E. MacPhee (American Museum of Natural History), and Wim Wendelen (Royal Museum for Central Africa, Tervuren) generously provided access to comparative specimens of extant anomalurids. We thank Laurent Marivaux (Université de Montpellier II) and Erik Seiffert (Stony Brook University) for kindly providing us with casts of fossil rodents from the early

\section{References}

Abouessa, A., Pelletier, J., Duringer, P., Schuster, M., Schaeffer, P., Métais, E., et al. (2012). New insight into the sedimentology and stratigraphy of the Dur At Talah tidal-fluvial transition sequence (Eocene-Oligocene, Sirt Basin, Libya). J. Afr. Earth Sci. 65, 72-90. doi: 10.1016/j.jafrearsci.2012.02.004

Arambourg, C. (1963). "Continental vertebrate faunas of the Tertiary of North Africa," in African Ecology and Human Evolution, eds. F. C. Howell and F. Bourliere (Chicago, IL: Aldine), 55-60.

Arambourg, C., and Magnier, P. (1961). Gisements de vertébrés dans le basin tertiaire de Syrte (Libye). C. R. Acad. Sci. Paris 252, 1181-1183.

Arnould-Saget, S., and Magnier, P. (1961). Découverte de dents de palaeomastodontes dans la région de Zella (Tripolitaine). Bull. Soc. Géol. France 3, 283-287.

Beard, K. C., Coster, P. M. C., Salem, M. J., Chaimanee, Y., and Jaeger, J.-J. (2015a). A new species of Apidium (Anthropoidea, Parapithecidae) from the Sirt Basin, central Libya: first record of Oligocene primates from Libya. J. Hum. Evol. doi: 10.1016/j.jhevol.2015.08.010

Beard, K. C., Coster, P. M. C., Salem, M. J., Chaimanee, Y., and Jaeger, J.-J. (2015b). "Biogeographic provincialism shown by Afro-Arabian mammals during the middle Cenozoic: climate change, Red Sea rifting and global eustasy," in Human Interaction with the Environment, Past and Present: Red Sea VI Proceedings, eds D. A. Agius, E. Khalil, E. Scerri, and A. Williams (Leiden: Brill).

Blanga-Kanfi, S., Miranda, H., Penn, O., Pupko, T., DeBry, R. W., and Huchon, D. (2009). Rodent phylogeny revised: analysis of six nuclear genes from all major rodent clades. BMC Evol. Biol. 9:71. doi: 10.1186/1471-2148-9-71

Bremer, K. (1994). Branch support and tree stability. Cladistics 10, 295-304. doi: 10.1111/j.1096-0031.1994.tb00179.x

Bugge, J. (1974). The cephalic arterial system in insectivores, primates, rodents and lagomorphs, with special reference to the systematic classification. Acta Anat. $87,1-159$.

Byrnes, G., and Spence, A. J. (2011). Ecological and biomechanical insights into the evolution of gliding in mammals. Int. Comp. Biol. 51, 991-1001. doi: 10.1093/icb/icr069

Churakov, G., Sadasivuni, M. K., Rosenbloom, K. R., Huchon, D., Brosius, J., and Schmitz, J. (2010). Rodent evolution: back to the root. Mol. Biol. Evol. 27, 1315-1326. doi: 10.1093/molbev/msq019

Coster, P., Benammi, M., Lazzari, V., Billet, G., Martin, T., Salem, M., et al. (2010). Gaudeamus lavocati sp. nov. (Rodentia, Hystricognathi) from the early Oligocene of Zallah, Libya: first African caviomorph? Naturwissenschaften 97, 697-706. doi: 10.1007/s00114-010-0683-x

Coster, P., Benammi, M., Salem, M., Bilal, A. A., Chaimanee, Y., Valentin, X., et al. (2012). New hystricognathous rodents from the early Oligocene of central Libya (Zallah Oasis, Sahara Desert): systematic, phylogenetic, and biochronologic implications. Ann. Carnegie Mus. 80, 239-259. doi: 10.2992/007.080.0304

Coster, P. M. C., Beard, K. C., Salem, M. J., Chaimanee, Y., Brunet, M., and Jaeger, J.-J. (2015). A new early Oligocene mammal fauna from the Sirt Basin, central Libya: biostratigraphic and paleobiogeographic implications. J. Afr. Earth Sci. 104, 43-55. doi: 10.1016/j.jafrearsci.2015.01.006

Court, N. (1995). A new species of Numidotherium (Mammalia: Proboscidea) from the Eocene of Libya and the early phylogeny of the Proboscidea. J. Vert. Paleontol. 15, 650-671. doi: 10.1080/02724634.1995.10011254
Cenozoic of North Africa. This research has been completed under the framework of a cooperative program between the Université de Poitiers (France), the University of Tripoli (Libya) and the University of Kansas (USA). We gratefully acknowledge financial support from the U.S. National Science Foundation (BCS 1157142 and BCS 1441585).

\section{Supplementary Material}

The Supplementary Material for this article can be found online at: http://journal.frontiersin.org/article/10.3389/feart. 2015.00056

Dawson, M. R., Li, C.-K., and Qi, T. (2010). The Diatomyidae (Mammalia, Rodentia) and bilophodonty in middle Eocene Asian rodents. Vert. PalAsiatica 48, 328-335.

Dawson, M. R., Marivaux, L., Li, C.-K., Beard, K. C., and Métais, G. (2006). Laonastes and the "Lazarus effect" in Recent mammals. Science 311, 1456-1458. doi: 10.1126/science.1124187

Dawson, M. R., Tsubamoto, T., Takai, M., Egi, N., Soe Thura Tun and Chit Sein (2003). Rodents of the family Anomaluridae (Mammalia) from southeast Asia (middle Eocene, Pondaung Formation, Myanmar). Ann. Carnegie Mus. 72, 203-213.

Delmer, C. (2009). Reassessment of the generic attribution of Numidotherium savagei and the homologies of lower incisors in proboscideans. Acta Palaeontol. Pol. 54, 561-580. doi: 10.4202/app.2007.0036

Ellerman, J. R. (1940). The Families and Genera of Living Rodents. Volume I: Rodents other than Muridae. London: British Museum (Natural History).

Fabre, P.-H., Hautier, L., Dimitrov, D., and Douzery, E. J. P. (2012). A glimpse on the pattern of rodent diversification: a phylogenetic approach. BMC Evol. Biol. 12:88. doi: 10.1186/1471-2148-12-88

Fejfar, O. (1987). Oligocene rodents from Zallah Oasis, Libya. Munchner Geowiss. Abh. A 10, 265-268.

Felsenstein, J. (1985). Confidence limits on phylogenies: an approach using the bootstrap. Evolution 39, 783-791. doi: 10.2307/2408678

Flynn, L. J., Jacobs, L. L., and Cheema, I. U. (1986). Baluchimyinae, a new ctenodactyloid rodent subfamily from the Miocene of Baluchistan. Am. Mus. Novitates $2841,1-58$

Fraser, L. (1852). Description of a new species of Anomalurus, from Fernando Po. Proc. Zool. Soc. Lond. 20, 16-17.

Gervais, P. (1849). "Rongeurs," in Dictionnaire Universel d'Histoire Naturelle, ed M. C. d'Orbigny (Paris: M. M. Renard, Martinet et Cie), 198-204.

Gervais, P. (1853). Description ostéologique de l'Anomalurus, et remarques sur la classification naturelle des rongeurs. Ann. Sci. Nat. Paris (3e sér.) 20, 238-246.

Gill, T. (1872). Arrangement of the families of mammals. Smithsonian Misc. Coll. 230, 1-98.

Goloboff, P. A., Farris, J. S., and Nixon, K. C. (2008). TNT, a free program for phylogenetic analysis. Cladistics 24, 774-786. doi: 10.1111/j.10960031.2008.00217.x

Grohé, C., Morlo, M., Chaimanee, Y., Blondel, C., Coster, P., Valentin, X., et al. (2012). New Apterodontinae (Hyaenodontida) from the Eocene locality of Dur At-Talah (Libya): systematic, paleoecological and phylogenetical implications. PLoS ONE 7:e49054. doi: 10.1371/journal.pone.0049054

Happold, D. C. D. (2013). "Family Anomaluridae," in Mammals of Africa. Volume III, Rodents, Hares and Rabbits, ed D. C. D. Happold (London: Bloomsbury Natural History), 602-617.

Huchon, D., Chevret, P., Jordan, U., Kilpatrick, C. W., Ranwez, V., Jenkins, P. D., et al. (2007). Multiple molecular evidences for a living mammalian fossil. Proc. Natl. Acad. Sci. U.S.A. 104, 7495-7499. doi: 10.1073/pnas.0701289104

Jackson, S. M. (2000). Glide angle in the genus Petaurus and a review of gliding in mammals. Mammal Rev. 30, 9-30. doi: 10.1046/j.1365-2907.2000.00056.x

Jackson, S. M. (2012). Gliding Mammals of the World. Melbourne, VIC: CSIRO Publishing.

Jaeger, J.-J., Beard, K. C., Chaimanee, Y., Salem, M., Benammi, M., Hlal, O., et al. (2010a). Late middle Eocene epoch of Libya yields earliest known 
radiation of African anthropoids. Nature 467, 1095-1098. doi: 10.1038/nature 09425

Jaeger, J.-J., Denys, C., and Coiffait, B. (1985). "New Phiomorpha and Anomaluridae from the late Eocene of north-west Africa: phylogenetic implications," in Evolutionary Relationships among Rodents: A Multidisciplinary Analysis, eds W. P. Luckett and J.-L. Hartenberger (New York, NY: Plenum Press), 567-588.

Jaeger, J.-J., Marivaux, L., Salem, M., Bilal, A. A., Benammi, M., Chaimanee, Y., et al. (2010b). New rodent assemblages from the Eocene Dur AtTalah escarpment (Sahara of central Libya): systematic, biochronological, and palaeobiogeographical implications. Zool. J. Linn. Soc. 160, 195-213. doi: 10.1111/j.1096-3642.2009.00600.x

Lavocat, R. (1973). Les Rongeurs du Miocene d'Afrique Orientale. 1. Miocene inferieur. Mém. Trav. Instit. Mont. 1, 1-284.

Lavocat, R., and Parent, J.-P. (1985). "Phylogenetic analysis of middle ear features in fossil and living rodents," in Evolutionary Relationships among Rodents: A Multidisciplinary Analysis, eds W. P. Luckett and J.-L. Hartenberger (New York, NY: Plenum Press), 333-354.

Li, Q. (2015). Eocene fossil rodent assemblages from the Erlian Basin (Inner Mongolia, China): biochronological implications. Palaeoworld. doi: 10.1016/j.palwor.2015.07.001. [Epub ahead of print].

Maddison, W. P., and Maddison, D. R. (2015). Mesquite: A Modular System for Evolutionary Analysis. Version 2.75. Available online at: http://mesquiteproject. org

Marivaux, L., Adaci, M., Bensalah, M., Gomes Rodrigues, H., Hautier, L., Mahboubi, M., et al. (2011). Zegdoumyidae (Rodentia, Mammalia), stem anomaluroid rodents from the early to middle Eocene of Algeria (Gour Lazib, Western Sahara): new dental evidence. J. Syst. Palaeontol. 9, 563-588. doi: $10.1080 / 14772019.2011 .562555$

Marivaux, L., Ducrocq, S., Jaeger, J.-J., Marandat, B., Sudre, J., Chaimanee, Y., et al. (2005). New remains of Pondaungimys anomaluropsis (Rodentia, Anomaluroidea) from the latest middle Eocene Pondaung Formation of central Myanmar. J. Vert. Paleontol. 25, 214-227. doi: 10.1671/02724634(2005)025[0214:NROPAR]2.0.CO;2

Marivaux, L., Essid, E. M., Marzougui, W., Ammar, H. K., Merzeraud, G., Tabuce, R., et al. (2015). The early evolutionary history of anomaluroid rodents in Africa: new dental remains of a zegdoumyid (Zegdoumyidae, Anomaluroidea) from the Eocene of Tunisia. Zool. Scripta 44, 117-134. doi: 10.1111/zsc.12095

Marivaux, L., Vianey-Liaud, M., and Jaeger, J.-J. (2004). High-level phylogeny of early Tertiary rodents: dental evidence. Zool. J. Linn. Soc. 142, 105-134. doi: 10.1111/j.1096-3642.2004.00131.x

Marivaux, L., and Welcomme, J.-L. (2003). New diatomyid and baluchimyine rodents from the Oligocene of Pakistan (Bugti Hills, Balochistan): systematic and paleobiogeographic implications. J. Vert. Paleontol. 23, 420-434. doi: 10.1671/0272-4634(2003)023[0420:NDABRF]2.0.CO;2

Martin, T. (1993). Early rodent incisor enamel evolution: phylogenetic implications. J. Mamm. Evol. 1, 227-254.

Martin, T. (1995). Incisor enamel microstructure and phylogenetic interrelationships of Pedetidae and Ctenodactyloidea (Rodentia). Berliner Geowiss. Abh. E. 16, 693-707

Matschie, P. (1894). Neue Säugethiere aus den Sammlungen der Herren Zenker, Neumann, Stuhlmann und Emin. Sit. Ber. Gesells. Naturforsch. Freun. Ber. 1894, 194-206.

Matschie, P. (1898). Eine neue mit Idiurus Mtsch. verwandte Gattung der Nagethiere. Sit. Ber. Gesells. Naturforsch. Freun. Ber. 1898, 23-30.

Montgelard, C., Bentz, S., Tirard, C., Verneau, O., and Catzeflis, F. M. (2002). Molecular systematics of Sciurognathi (Rodentia): the mitochondrial cytochrome $\mathrm{b}$ and 12S rRNA genes support the Anomaluroidea (Pedetidae and Anomaluridae). Mol. Phylogenet. Evol. 22, 220-233. doi: 10.1006/mpev.2001.1056

Montgelard, C., Forty, E., Arnal, V., and Matthee, C. A. (2008). Suprafamilial relationships among Rodentia and the phylogenetic effect of removing fastevolving nucleotides in mitochondrial, exon and intron fragments. BMC Evol. Biol. 8:321. doi: 10.1186/1471-2148-8-321

Pickford, M., and Mein, P. (2006). Early middle Miocene mammals from Moroto II, Uganda. Beitr. Paläontol. 30, 361-386.

Pickford, M., and Mein, P. (2011). New Pedetidae (Rodentia: Mammalia) from the Mio-Pliocene of Africa. Estud. Geol. 67, 455-469. doi: 10.3989/egeol.40714.202
Pickford, M., Senut, B., Morales, J., Mein, P., and Sanchez, I. M. (2008) Mammalia from the Lutetian of Namibia. Mem. Geol. Surv. Namibia 20, 465-514.

Pickford, M., Senut, B., Musalizi, S., and Musiime, E. (2013). The osteology of Nonanomalurus soniae, a non-volant arboreal rodent (Mammalia) from the early Miocene of Napak, Uganda. Geo Pal Uganda 7, 1-33.

Ruf, I., Frahnert, S., and Maier, W. (2010). The chorda tympani and its significance for rodent phylogeny. Mamm. Biol. 74, 100-113. doi: 10.1016/j.mambio.2008.01.002

Sallam, H. M., Seiffert, E., Bouer, D., and Simons, E. (2010c). Postcranial morphology of an anomaluroid rodent from the late Eocene Egypt (sic). J. Vert. Paleontol. 30, 155A. doi: 10.1080/02724634.2010.501439

Sallam, H. M., Seiffert, E. R., and Simons, E. L. (2010a). A highly derived anomalurid rodent (Mammalia) from the earliest late Eocene of Egypt. Palaeontology 53, 803-813. doi: 10.1111/j.1475-4983.2010 00962.x

Sallam, H. M., Seiffert, E. R., and Simons, E. L. (2012). A basal phiomorph (Rodentia, Hystricognathi) from the late Eocene of the Fayum Depression, Egypt. Swiss J. Palaeontol. 131, 283-301. doi: 10.1007/s13358-012-0039-6

Sallam, H. M., Seiffert, E. R., Simons, E. L., and Brindley, C. (2010b). A large-bodied anomaluroid rodent from the earliest late Eocene of Egypt: phylogenetic and biogeographic implications. J. Vert. Paleontol. 30, 1579-1593. doi: 10.1080/02724634.2010.501439

Savage, R. J. G. (1969). Early Tertiary mammal locality in southern Libya. Proc. Geol. Soc. Lond. 1657, 167-171.

Savage, R. J. G., and White, M. E. (1965). Two mammal faunas from the early Tertiary of central Libya. Proc. Geol. Soc. Lond. 1623, 89-91.

Tabuce, R., Jaeger, J.-J., Marivaux, L., Salem, M., Bilal, A. A., Benammi, M., et al. (2012). New stem elephant-shrews (Mammalia, Macroscelidea) from the Eocene of Dur At-Talah, Libya. Palaeontology 55, 945-955. doi: 10.1111/j.14754983.2012.01163.x

Thomas, H., Roger, J., Sen, S., Pickford, M., Gheerbrant, E., Al-Sulaimani, Z., et al. (1999). "Oligocene and Miocene terrestrial vertebrates in the southern Arabian Peninsula (Sultanate of Oman) and their geodynamic and palaeogeographic settings," in Fossil Vertebrates of Arabia, eds P. J. Whybrow and A. Hill (New Haven: Yale University Press), 430-442.

Thomas, O. (1887). Diagnoses of two new Central-African Mammalia. Ann. Mag. Nat. Hist. 20, 440 .

Thorington, R. W. Jr. (1984). Flying squirrels are monophyletic. Science 225, 1048-1050.

Vesely, J. (1985). Sheet Zallah (NH 33-16), Geological Map of Libya, Scale 1:250,000, Explanatory Booklet. Tripoli: Industrial Research Centre.

Vianey-Liaud, M., and Jaeger, J.-J. (1996). A new hypothesis for the origin of African Anomaluridae and Graphiuridae (Rodentia). Palaeovertebrata 25, 349-358.

Vianey-Liaud, M., Jaeger, J.-J., Hartenberger, J.-L., and Mahboubi, M. (1994). Les rongeurs de l'Eocène d'Afrique nord-occidentale [Glib Zegdou (Algérie) et Chambi (Tunisie)] et l'origine des Anomaluridae. Palaeovertebrata, 23, 93-118.

Waterhouse, G. R. (1842). Observations on the Rodentia. Ann. Mag. Nat. Hist. 10, 197-203. doi: 10.1080/03745484209445223

Wilson, D. E., and Reeder, D. M. (eds.). (2005). Mammal Species of the World. A Taxonomic and Geographic Reference, $3 r d$ Edn. Baltimore: Johns Hopkins University Press.

Winkler, A. J. (1992). Systematics and biogeography of middle Miocene rodents from the Muruyur Beds, Baringo District, Kenya. J. Vert. Paleontol. 12, 236-249.

Conflict of Interest Statement: The authors declare that the research was conducted in the absence of any commercial or financial relationships that could be construed as a potential conflict of interest.

Copyright (C) 2015 Coster, Beard, Salem, Chaimanee and Jaeger. This is an openaccess article distributed under the terms of the Creative Commons Attribution License (CC BY). The use, distribution or reproduction in other forums is permitted, provided the original author(s) or licensor are credited and that the original publication in this journal is cited, in accordance with accepted academic practice. No use, distribution or reproduction is permitted which does not comply with these terms. 